\title{
Illustrations for Encyclopedia Erupting Mountain Theme as Visual Culture
}

\author{
${ }^{1}$ Purmaningrum Maeni ${ }^{2}$, Firli Herdiana ${ }^{2}$ and AsiahHanifahQudwatunna. ${ }^{3}$ \\ Visual Communication Design Study Program, Faculty of Arts and Literature \\ Setiabudhi 193 Bandung West Java Indonesia \\ purmaningrum@unpas.ac.id
}

Indonesia's geographical location in the growth zone of three plates namely Eurasia, Indo-Australia and Pacifica or commonly known as ring of fire, causes Indonesia to have many active volcanoes. The study intends to determine the design of illustrations in the encyclopedia of volcanoes as an alternative learning media for for inspiring the students. To collect detailed actual information that describes the symptoms of nature as well as the situation of social symptom conditions then this research is carried out with descriptive qualitative and quantitative research methods. This study uses illustration theory and visual culture as the main reference literature. Visual culture is an interdisciplinary field with visual concepts as the basis for the study of knowledge and understanding. One part of visual culture that has a very important role in this research is illustration. Illustration design is conveyed through drawings, illustrations, or photos about disaster situations and conditions that are equipped with narratives though effective language. It is expected that by the illustrations through visual images and combined with the narrative the interest of students, especially children can be more aroused so that the information presented can be more quickly captured and understood.With the availability of the book Encyclopedia of Mount Erupting for elementary school students, it is expected that knowledge about the erupting mountain can be conveyed interestingly so that children can have better understanding of the causes and how to deal with the disaster of erupting mountains.

Keywords:Encyclopedia, Illustration, Book, Mountain Eruption, Visual Culture.

\section{Introduction}

Natural disasters are a condition that can be experienced by every human being that occur in certain areas and can cause damage to nature as well as existing facilities. Natural disasters can caused by human actions such as floods, landslides and forest fires and also caused by the nature state itself, such as earthquakes, tsunamis, typhoons (angina nipple pickaxe) and drought. Natural phenomena are natural events that occur caused by nature itself. There are natural phenomena that harming people and environment, destroying property even taking lives, but there are also natural phenomenon that give us benefit such as the occurrence of day and night, rain as well as dew.

Discussing the socialization of natural disasters and strategic in dealing with it is a way in order to reduce the victims and the impacts that occur 
due to natural disasters. The phenomenon is our country is located in the growth zone of three plates namely the Eurasian plate, the Indo Australia plate, and the Pacific plate so that Indonesia has numerous volcanoes called ring of fire. Consequently Indonesia is always has lots of natural disaster such as earthquakes, erupting mountains, tsunamis and others. In that case, we must be ready to face various disasters and overcome them to minimize victims. In Social Science subjects we focus on social cases about natural disasters at the same time introduce to elementary school students on how to deal with natural disasters. The issues of teaching and learning conducted in public and private elementary schools are: (1) do not know or do not care in facing natural disasters. (2) Socialization media for natural disaster management (3) Alternative learning media for inspiring the students.
In the creation of this learning media, the targeted audiences are elementary school students grades 4 , 5, and 6. They love the exposures that contain adventure stories, mysteries, tensions, and knowledge because they see images. The teaching method sometimes very limited and very monotonous which only focus to lecturing, question and answer, discussion and simulation so that the learning experience obtained by learners is very unvaried and they difficult to understand the message conveyed by the teacher. The color identification stage of the current alternative media is adapted to the taste of the targeted audience, so that students easy to comprehend and memorize the topic presented in the picture.

A volcano is a crater pit or cracks in the earth's crust where magma or other liquid gases come out to the earth's surface. Materials that are fused to the surface of the earth generally form a cone of baited. 
Volcanoes are classified into two sources of eruptions, namely central eruptions which is eruptions that exiting through the main crater and side eruptions that is eruptions which coming out of the slopes of their bodies, slit eruptions which is eruptions that appear in cracks / faults and can extend up to several kilometers, eccentric eruptions is side eruptions but magma comes out not from the center that deviates sideways but directly from the magma kitchen through its own crater based on the degree of fragmentation and it's extent, also based on the eruptions strength and smoke poles height.

\section{Literature Review}

\section{Illustrations.}

Illustration according to experts has several definitions quoted from the journal, namely:

Rohidi $(1984 ; 87)$ argues that the definition of illustration in relation to fine art is the depiction of something through visual elements in order explain or beautify a text, so that the reader can feel the impressions and traits of motion of the story presented directly through his own eyes,

Marta Thoma in Sofyan (1994:171) says that illustrations in relation to paintings develop along the same plot in history and in many ways, both are the same.

Soedarso (1990:1) explains that illustration is an image captured for some purposes which can provide an explanation or accompany a definition such as a short story in a magazine.

\section{a. The Function of Illustration}

Quoted from the journal, there are several illustration functions in general. The functions of the illustration are as follows (Kusrianto 2009:70-71):

1. Descriptive function is to replace the description of something verbally and narratively by using long sentences. 
2. Expressive function in presenting and expressing an abstract idea, feeling, intention, situation or concept becomes real so that it is easy to understand.

3. Analytical function or structure can show details part by part of an object or system or process to make it easier to understand.

4. This qualitative function is often used to create lists, tables, graphics, cartoons, photos, drawings, sketches and symbols.

\section{b. The Purpose of Illustration}

Illustrations aim to explain or decorate a story, poem, writing or information. The purpose of the illustration is:

1. Illustration aims to clarify the message or information conveyed.

2. Illustration aims to give a variety of teaching materials to be more interesting, motivating, communicative, and also make the readers understand the message easily.

3. Illustration aims to make the reader memorize the concepts and ideas conveyed (Kusrianto, 2009:70)

\section{c. Illustrations Types}

Following are the types of illustration is:

1. Naturalist illustration is an image that has the same shape and color as the reality in nature without any reduction or addition.

2. Decorative illustration is an image that serves to decorate something with a simplified shape or exaggerated with a certain style.

3. Cartoon image is a picture that has a funny shape or has certain characteristics.

4. Caricature image is a picture of criticism or satire that in its depiction has deviation of body proportions.

5. Pictured story is a kind of comic or picture accompanied by text. 
6. Textbook illustration (Encyclopedia) has a function to elucidate the text or an event both scientific and part image.

7. Imaginary illustration is an image that produced through imaginative processing.

\section{Definition of Book}

Buku in Indonesian, books in English, das Buch in German and "boek" in Dutch or bilbos in Greek have the same meanings. The Great Dictionary of The Indonesian Language (2003:471) defines book as collectin sheets of paper with binding, written or blank. According to the Oxford dictionary (2010: 195) book is a work written or printed consists of pages that are glued or sewn together on one side and tied to the cover. Pictured books can be grouped into several types.

1. A concept book is a book that presents concepts using one or more examples to help understanding the concepts that are being developed.
2. Pictured storybook contains messages through illustrations and written text. These two elements are important elements of the story. These books contain a variety of themes that are often based on the experiences of children's daily lives.

3. Textbooks are mandatory references used in schools that contain learning materials in improving faith and piety, ethics and personality, ability to master knowledge and technology, sensitivity and aesthetic ability, physical and health potentials compiled based on national standards of education.

4. Encyclopedia book is a reference or collection of writings that explain a lot of information.

\section{Encyclopedia}

The definition of encyclopedia is a collection of writings containing explanations of various information concerning a particular knowledge or science that is presented broadly, completely, and arranged 
alphabetically or in categories and equipped with illustrations, images, and other media elements that can help understand the concept. The term encyclopedia comes from the Greek, enkykliospaideia which means a circle or comprehensive teaching. Thus the initial meaning of the encyclopedia is a plenary education that encompasses all circles of science. Encyclopedias are often mixed with dictionary. Although the encyclopedia does develop from dictionary however it has its own differences.

Encyclopedias are often taken as reference material because they contain information about various things or fundamental and general sciences and supported by definitions, backgrounds, and bibliographic data arranged alphabetically and systematically. In addition, the encyclopedia is equipped with an index corner, which is a guide of a term to the number, volume, and page number that making it easier to use in the search for information quickly and precisely.

\section{Visual Culture}

The term culture is a complex thing that ultimately leads every human being continously to reach, research, and try to grasp how culture is defined, practiced, and embodied. One categorization of the culture that seemingly tries to make sense of all the rest which is visual culture.

Lauren Schleimer defines visual culture from an anthropological point of view. He stated that visual culture is a termthat refers to the tangible, or visible, expressions by a people, a state or a civilization, and collectively describes the characteristics of that body as a whole.

Visual culture is an interdisciplinary field with visual concepts as the basis for the study of knowledge and understanding.Leah

Houston articulates, "visual culture is a way of studying" the world and its relations through means of "art history, 
humanities, sciences, and social sciences.This relates to everything that a person sees in their daily life, including pictures, photos, films, illustrations, paintings, and everything that exists and appears in our culture that is communicated through visual media.

Visual culture flows in every system of people's lives, including in the economic, social, political, and scientific systems. The life system of 21st century society is very visual and multisensory.Images (photographs, pictures, illustrations, videos, and so on) precipitate beyond the realm of contemporary art; they are active elements that coordinate functions of the internet, journalism, marketing, computer technologies, systems of surveillance, scientific practice, and more.

Illustrations, which contain many visual elements, are a part of visual culture which has an equally important role in the life and communication system
society.Illustrations can be used as a means of communication that is able to express various scientific phenomena both naturally and socially. It includes pictures that are often used as a means of representing and explaining certain events that occur in our daily environment.

\section{Research Methods}

The research was conducted in Bandung, with the target audience is students aged 8-12 years old around grades 4,5 and 6 , because that age is the most important period in wanting to try new things. The research method used is combining the quantitative and qualitative technique. The aim is to create a systematic, factual and accurate description of the facts, traits and relationships between investigated phenomena (Nazir, 1998).

Based on the existing data, students' ignorance towards a natural disaster because of their lack of understanding that a disaster can lead to a loss of 
property even life. Responsiveness in natural disaster events can be grown by learning from the childhood hoping that elementary school students can understand and be able to respond to disasters as far as they can. And teaching by using visuals or images with captions can be more or quickly understood by elementary school students because they will not only read boring explanation that difficult to understand.

\section{Target Audience}

Demographics: placed in the panyileukan city of Bandung, West Java.

- Gender: Male and Female

- Age: children (9-12 years old)

- SES: Top

Geographical: SDN 268 panyileukan, SDN 262 panyileukan, SD Al-Biruni and SD Juara.

Psychographic: elementary school children have difficulty in understanding about the response on Mountain Eruption Disaster.

\section{Visual Analysis}

Following is the results of the analysis taken from observations and questionnaires that have been done:

\section{a. What visual tools do you usually use to learn?}

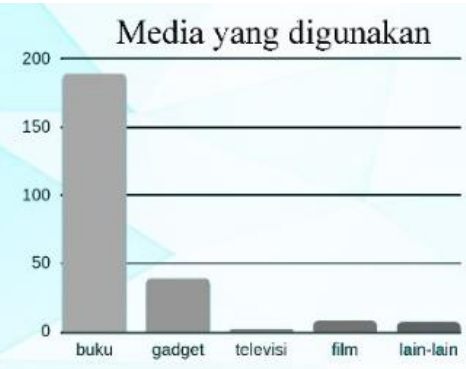

Based on figure 3.2.above, the media that is often used is books and almost comparable to gadgets.

\section{b. Among the following visual media, which one you like the most and often use, choose one of the}

Based on the table above, it can be known that children who like comics as much as 65 are almost comparable to fewer animations. This suggests that children show more interest in images in visual media.

The table below shows an interest in the style of images and book media: 


\begin{tabular}{|c|c|c|c|c|c|}
\hline $\begin{array}{c}\text { Picture } \\
\text { Preferen }\end{array}$ & SD & SD & SD & SD & Al- \\
N & N & Juml \\
ni & 26 & 26 & ah \\
\hline $\begin{array}{c}\text { Animati } \\
\text { on }\end{array}$ & 19 & 24 & 10 & 22 & 75 \\
\hline Comic & 16 & 21 & 12 & 16 & 65 \\
\hline $\begin{array}{c}\text { Children } \\
\text { movie }\end{array}$ & 12 & 7 & 9 & 6 & 34 \\
\hline Cartoon & 9 & 11 & 15 & 11 & 46 \\
\hline $\begin{array}{c}\text { Children } \\
\text { serial }\end{array}$ & 2 & 0 & 0 & 0 & 2 \\
\hline Game & 10 & 14 & 17 & 7 & 48 \\
\hline $\begin{array}{c}\text { Pictured } \\
\text { book }\end{array}$ & 20 & 25 & 12 & 23 & 80 \\
\hline
\end{tabular}

The above chart reveals that children prefer the Japanese image style (manga), based on the observations, interviews and questionnaires that have been done it was divulged that children prefer semi-realist because it is simple like manga so that the visuals depicted are easier to understand.

2) Why do you like the book?.

Tabel 3.3. Media Visual

\section{WHY DO YOU LIKE THE BOOK?}

- menyenangkan

- mudah memahami dalam belajar

- tidak membosankan

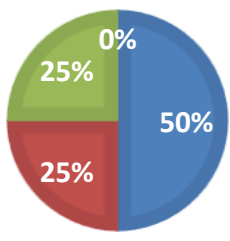

\section{WHICH ONE DOES THE KIDS PREFER?}

- Jepang (manga)

- Amerika (marvel)

- Eropa (tintin)

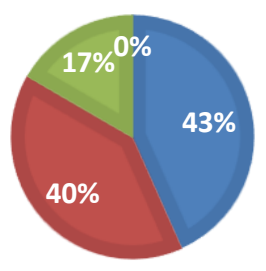

Figure 3.3. Illustration 
weaknesses, opportunities, and threats to determine an alternative that has been chosen. The elaborations of SWOT analysis of alternative media in the form of visuals or images are as follows:

\section{a. Strength:}

The strength of this alternative media books is in the illustration so that students can understand faster the information given, furthermore the communicative strategy by using illustration can make them be more focus in reading the book.

\section{b. Weakness:}

The weakness is that visualization must always be supported by a description in the form of sentences in order to be understood. The sentence must be in concise and clear language.

\section{c. Opportunity:}

Alternative media in the form of visualization / images can widen the students' imagination so that that can directly imagine how a natural disaster happened. Students will be able to feel natural and social events or symptoms as if they were at the location of the disaster.

\section{d. Threat:}

The threat that alternative media books face is digital media and gadget. Children today prefer playing games and watching youtube on the internet than reading books.

\section{4. $5 \mathrm{~W}+1 \mathrm{H}$ Analysis}

Analysis of what - who - why where - when - how $(5 \mathrm{~W}+1 \mathrm{H})$ is required to know or to observe and explore the problems in this study covering what, who, how, where, when, and how much. Following is the explanation:

\begin{tabular}{|l|l|l|}
\hline \multicolumn{1}{|c|}{ What } & \multicolumn{1}{c|}{ Who } & \multicolumn{1}{c|}{ Why } \\
\hline Recent & early & Because \\
years in & childhood, & Indonesia is \\
Indonesia, & adolescen & part of an \\
there has & ce to & archipelago \\
been a & adulthood & geographica \\
phenomen & become & lly located \\
on of & victims of & between \\
various & natural & three large \\
\hline
\end{tabular}




\begin{tabular}{|c|c|c|}
\hline $\begin{array}{l}\text { types of } \\
\text { disasters } \\
\text { happened } \\
\text { in the } \\
\text { country. } \\
\text { Starting } \\
\text { from } \\
\text { earthquake } \\
\text { s, flash } \\
\text { floods, } \\
\text { erupting } \\
\text { mountains, } \\
\text { putting } \\
\text { pickaxes } \\
\text { and some } \\
\text { other } \\
\text { disasters } \\
\text { occurred } \\
\text { without } \\
\text { knowing } \\
\text { the } \\
\text { seasons. }\end{array}$ & $\begin{array}{l}\text { disasters. } \\
\text { Five years } \\
\text { ago, 2,479 } \\
\text { victims } \\
\text { from the } \\
\text { web } \\
\text { bnpb.go.i } \\
\text { d. }\end{array}$ & $\begin{array}{l}\text { plates } \\
\text { (Eurasia, } \\
\text { indoaustrali } \\
\text { a, and the } \\
\text { Pacific), the } \\
\text { country is } \\
\text { vulnerable } \\
\text { to natural } \\
\text { disasters. }\end{array}$ \\
\hline Where & When & How \\
\hline $\begin{array}{l}\text { All over } \\
\text { Indonesia } \\
\text { there are } \\
\text { natural } \\
\text { disasters. }\end{array}$ & $\begin{array}{l}\text { Since } 5 \\
\text { years ago } \\
\text { until now } \\
\text { there are } \\
\text { often } \\
\text { natural } \\
\text { disaster }\end{array}$ & $\begin{array}{l}\text { Number of } \\
\text { flood events } \\
3,297, \\
\text { landslides } \\
2,814, \\
\text { abrasion } 71, \\
\text { putting } \\
\text { pickaxe } \\
3,169, \\
\text { drought } 34, \\
\text { forest fires } \\
\text { \& land } 459, \\
\text { earthquakes } \\
78, \text { tsunami } \\
2, \text { volcanic } \\
\text { eruptions } 29 \\
\text { times. }\end{array}$ \\
\hline
\end{tabular}

Based on SWOT/5W $1 \mathrm{H}$ analysis, alternative media in the form of visuals or images can be understood faster. However the weakness of alternative media such as visualization must always be supported by a description in the form of a sentence in order to be understood easily. The images can develop students' imagination further so that they can imagine how a natural disaster such as a volcano erupts.

Nevertheless visualization/image of natural disasters has an imperfection or incompatibly between drawings by latest technology with manual images, therefore since technology continues to grow rapidly the illustrator must be able to follow and utilize it.

\section{Results and Discussion}

A communication strategy to convey information about disaster mitigation by using drawing and illustration is expected to be suitable with targeted 
audience that psychologically has a high curiosity and to provide a real impression of the effects. Hopefully the message to be conveyed can be liked by children and easy to be understood. The strategy presented is in the form of exhortation to give awareness about volcanoes. Therefore pictured book is chosen as graphic medium for delivery the messages, as well as the dissemination means of science and information, such as education and moral value.

\section{Character Studies}

The concept of character portrayal is based on several versions of character depictions that are used as visual references and from the results of questionnaires to children. Then the images that appear are depictions of manga and semi-realist image style versions because they are preferred by children and portrayed by wearing elementary school, teacher and BNPB (National Disaster Management Agency) uniform because it creates an atmosphere close to children environment.

1. Zahra

2. Zayd

3. Teacher and BNPB

\section{Storyline}

Storyline below elucidate some expressions such as shock, fear and knowing:

1. Zahra and Zayd finds out what caused the disaster.

2. Mr. Rahman said look at the picture of the erupting mountain. Zayd says "Wow how come?", Zahra says "so it looks like this".

3. Zahra says "oh, the crater was from a volcanic eruption" and Zayd said "Yes, every volcano must have craters caused by eruptions".

4. Zayd surprised knowing there are many types of erupting mountains.

5. Zayd says "This is scary, the lava was so hot”. Zahra and Zayd express 
fear because of the aftermath of the volcano.

6. Zahra says Allahuakbar, because volcanoes have benefits.

7. BNPB (National Disaster Management Agency) agent Rahman explains how to avoid this kind of disaster. Zahra and Zayd say they understand.

8. Zayd says "Run away quickly from the volcano area because of recognizing the disaster alert status" Zahra says "run quickly and be hurry to evacuate".

\section{Layout}

Layout used in the guidebook

displaying more images because

children like to read book with interesting pictures. The size of the text as a supporting media is $40 \times 25$ $\mathrm{cm}$.

\section{Picture Styles}

The image style tha taken is Semi Realist which starts with drawing manually and then screened to computer and being processed to digitalize by Wacom in vector-vector images in photoshop and indesign applications.

\section{Coloring techniques}

For coloring technique in using illustrations can be seen from the tone of the volcano with a digital vector process that was originally sketched manually and scanned and then inserted intothe computer and the final result is coloring.

\begin{tabular}{|c|c|}
\hline Dark blue & White \\
$R: 183$ G:222 & $R: 255 G: 255$ \\
B:232 & $B: 255$ \\
\hline
\end{tabular}

\section{Typography}

The font used is the one that close to the children's world while reading the pictured books, namely cartoon-style with readability level that corresponds to the child's visibility when reading.

Times new roman

ABCDEFGHIJKLMNOPGRSTUVWXY $\mathrm{Z}$ abcdefghijklmnopqrstuvwxyz 1234567890 
DFPOP1-W9

ABCDEFGHIJKLMNOPGRSTUVWXY

$\mathrm{Z}$ abcdefghijklmnopqrstuvwxyz 1234567890

\section{Book's Content}

The content of this encyclopedia are:

- Understanding

- What causes

- Traits

- Types

- Consequences

- benefits

- How to avoid

- Negative and positive impacts

- Get to know the status

\section{Illustration Application on the} Encyclopedia Volcano Eruption Theme

This encyclopedia is arranged into several parts to make it easy for children to learn and understand. The illustrations created will provide clear information about the erupting mountain.

\section{a. Cover}

The concept of designing the cover is using illustrations of children as well as people who are running away from the erupting mountain because it matches the impression of the erupting mountain. Typography for the font used still uses cartoonish nuances which intended to make children prefer this book. For other information such as the description in it still use the same letter with the cover to make the logo of the erupting mountain, namely by using the letter DFPOP1-W9.

Here are the cover results of the guidebook and layout of the inside section:

\section{b. The First and the Last Pages}

Illustration for the preface and the table of contents is the beginning part while the conclusion and the closing is the ending part. The font used in this book are times new romance similar to the contents of the book to highlight the consistency and 
and then up and then 2 columns like

z. The color to be used is light blue and white color because the atmosphere of this color is suitable for the natural environment and the texture color is due to the real texture of the volcano.

\section{e. The Consequences and Benefits of Volcano Pages}

Illustration for the contents of the manual is using 2 characters that have been created according to the target audience, namely Zahra and Zayd that will guide children in knowledge with additional photos of volcanoes to easily understand the drawings. The font used in this book is times new romance similar with the contents of the book. The layout uses the bottom up illustration taking 2 curious characters, and the page is read from the left side to the right page (see this image) free to read like a play box.. The color to be used is light blue and white because the impression of this color is exact with the natural environment.

\section{f. How to Avoid the Disaster Pages}

Illustration for the contents of the guidebook is using 3 characters that have been made in accordance with the results of the target audience, namely Zahra, Zayd and BNPB (National Disaster Management Agency) MrRahman who will guide children in knowing and informing, also adding the photos of volcano news to clarify. The font used in this book is times new romance similar to the contents of the book. The layout uses the illustration at the bottom up taking 3 curious characters (see this image) on how to avoid the disaster. The color to be used is light blue and white because the tone of this color is accurate with the natural environment.

\section{g. The Negative and Positive Effects of Volcano Page}

The illustrations for the contents of the manual add both negative and positive effects of volcano. The font used in this book are times new 
roman similar with the contents of the book. The layout is using a curious illustration (see this image) beginning moving up like $\mathrm{z}$ and ended down decreasing. The colors to be used are light blue and white because the ambiance of this color matches the natural environment

\section{h. Recognizing the Disaster Status Page}

Illustration for the contents of the handbook is using 2 characters that have been made according to the target audience, namely Zahra and Zayd characters who will guide the children in knowing and informing the disaster alert status. The font used in the contents of this book is times new romance. The layout draws using the top down illustration by taking 2 curious characters (see this image). The color to be used is light blue and white because the atmosphere of this color is defined the natural environment.

\section{Conclusion}

The illustration design of this encyclopedia is expected to add the knowledge of the erupting mountain disaster, which can be enriched and refined. A good understanding of the phenomenon in general is very necessary in order to be able to respond correctly and well prepared in facing the disaster. The existences of interesting media that describes the phenomenon of erupting mountains that consist of the initial symptoms, before, during the event, as well as post-event, including natural symptoms as well as social symptoms are very necessary. Therefore we created an encyclopedia book that can be useful and enrich students' knowledge about the erupting mountain. The encyclopedia book is very easy to understand and with semi-realist illustrations it is not too complicated to read.

This book is designed based on the results of questioner towards students on understanding the 
natural disasters of erupting mountains, data collection, and enriched with semi-realist illustrated images. As for the semi-realist image style in this encyclopedia book is described clearly and structured that hopefully the message about the erupting mountain will be easily studied by the targeted audience that is elementary school children as a source of information other than textbooks.

\section{Refrences}

Daryanto, Media Pembelajaran, Jogjakarta: Gava Media, 2010

Adi Kusrianto, Pengantar Desain Komunikasi Visual, Yogyakarta: Andi Offset, 2007

Lia Anggraeni S, and Kirana Nathalia, Desain Komunikasi Visual. Bandung: Nuansa Cendikia, 2014

Suriyanto Rustan, Layout - Dasar dan penerapannya, Jakarta: PT Gramedia Pustaka Utama, 2014

Yulianti, Pengantar Seni Rupa, Bandung: Cipta Idea Pustaka, 2009

Dr. Dedi Dermon, Geografi bencana alam, Jakarta: PT Raja Grafindo Persada, 2015
Lif Khoiru Ahmadi, M.Pd. \& Sofan Amri, S.Pd, mengembangkan pembelajaran IPS terpadu, Jakarta: Prestasi Pustaka, 2011

Angus Stevenson, Oxford Dictionary of English, New York: Oxford University Press, 2010

Maryono, Ishartati, Peni Bektiningsih, Supyoro. "Ensiklopedia Koleksi Rujukan dengan informasi mendasar dan lengkap soal ilmu pengetahuan", Informasi dan Publikasi

Rosalia Destarisa Budiani, "Perancangan Buku Ilustrasi Sebagai Media Kampanye Pengenalan Permainan Tradisional Jawa Tengah” Skripsi, FSRD,UNS, Surakarta, Indonesia.

Gemmel, Mallory. “Arts Theori: Visual Culture". https://www.artshelp.net/arttheory-visual-culture/ 


\section{Biografi}

Purmaningrum Maeni, born in Tulungagung, August 28, 1978, earned a Bachelor's Degree (S.Sn.) in the Visual Communication Design Study Program, Pasundan University in 2003 and a Masters Degree (M.Ds) in the Design Study Program, Bandung Institute of Technology in 2014. I work as a Lecturer in the Visual Communication Design Study Program, Pasundan University and as a teacher / therapist at the Art Therapy Center Bandung. Active as a member in AIDIA (Asosiasi Profesional Desain Komunikasi Visual Indonesia). Co-wrote in the books chapter "Olah Rasa IlustrasiSunda" entitled "Gaya Gambar Realis Hitam Putih pada Ilustrasi"

Firli Herdiana, Deputy Director of Special Education at Art Therapy Center Widyatama. In addition to teaching graphic design for disabled students at ATC Widyatama, and adjunct lecturer atVisual Communication Design Study Program,Pasundan University. Firli established an ecommerce platform for disability creators www.thespecial.id. This platform is a place for disabled creators to promote their work, so that they become productive and independent. Firli won the Start-Up Competition at UK Indonesia Tech Hub, Youth Economic Leadership Program by Bank Indonesia and ORBIT BEKRAF RI. Firli also created the Nyontex educational game to poke and remind people not to do bad things, like cheating. Firli won the 3rd place in Flash Game Creation - Student Category - National Level and Favorite Champion in Graphic Design - High School / Se-degree
Category
West
Java
Level 
